\title{
Numerical Modeling of Water Movement from Buried Vertical Ceramic Pipes through Coarse Soils
}

\author{
Zena Kamil Rasheed* Maysoon Basheer Abid** \\ *,**Department of Water Resources/College of Engineering/University of Baghdad \\ *Email: kamel_zena @yahoo.com \\ ** Email:dr.maysoonbasheer @ gmail.com
}

(Received 22 March 2017; accepted 14 June 2017)

https://doi.org/10.22153/kej.2017.06.003

\begin{abstract}
Problem of water scarcity is becoming common in many parts of the world. Thus to overcome this problem proper management of water and an efficient irrigation systems are needed. Irrigation with buried vertical ceramic pipe is known as a very effective in management of irrigation water. The two- dimensional transient flow of water from a buried vertical ceramic pipe through homogenous porous media is simulated numerically using the software HYDRUS/2D to predict empirical formulas that describe the predicted results accurately. Different values of pipe lengths and hydraulic conductivity were selected. In addition, different values of initial volumetric soil water content were assumed in this simulation as initial conditions. Different values of applied head were assumed in this simulation as a boundary conditions. In general, a good agreement was obtained when comparing the predicted results with available measured values. The results of this research showed that greater spreading occur in vertical direction. Increasing applied heads, initial soil water contents, pipe hydraulic conductivities, cause increasing the size of wetting patterns. Also the results showed that the empirical formulas which can be used for expressing the wetted width and depth in terms of applied head, initial soil water content, application time, pipe hydraulic conductivity, and pipe length, are good and can be used as a designing equations.
\end{abstract}

Keywords: Numerical modeling, HYDRUS, soil water content, wetting patterns, HYDRUS, vertical ceramic pipe.

\section{Introduction}

Subsurface irrigation is one of the most methods perfectly suited for a specific amount of water and applied directly to the root zone, and thus reduce the losses resulting from the evaporation, conveyance, and deep percolation. Some media that are used to transport water for irrigation under the surface, including pots, porous clay pipes, and plastic drip lines with emitters where water leaks or penetrates into the soil, thus increasing the moisture content in the soil. Irrigation systems below the soil surface are becoming increasingly public, since making better water use efficiency for agriculture. It significant in many parts of the world that have limited water resource. This method of irrigation in some arid and semi-arid regions of the world has been used with great success. Irrigation with buried vertical ceramic pipe is analogous to drip irrigation since water leaks out from ceramic pipe and wets the surrounding soil along the length of the pipe. Several studies have been conducted on subsurface ceramic pipe systems. Reference [6], stated that irrigation by buried clay pot is an ideal, well-suited, and well-known for small-scale farms in different parts of the world. This type of irrigation gives ten times better than traditional surface irrigation also better than systems of drip irrigation. Clay pot irrigation is efficient in difficult conditions of limited water resources, high salinity, and limited supply of water. Reference [5], investigated the relations between the physical and hydraulic parameters in 
subsurface irrigation. They used a numerical model for simulating infiltration through porous pipe and studied the relations among different parameters such spacing between laterals, depth of installation, time of irrigation, pipe hydraulic conductivity, and the hydraulic head that affecting the flow process under subsurface porous pipe irrigation. They indicated that the wetted area was affected to the depth of installation and the water applied volume, soils hydraulic conductivity and an inverse relation between the depth of installation and the lateral spacing of porous clay pipe. Reference [8], studied and tested the porous clay pipe in the greenhouse. They developed a simple analytical model by using a dimensional analysis method to simulate the wetted soil shape under porous pipe. The statistical analysis were used to find the accuracy of the work. They indicated from statistical comparison that the model can be used to describe the wetted soil shape. Reference [3], tested a new form of vertical installation instead of horizontal installation of the porous clay pipe. The system has been designed for three pipes lengths that were $(30,45$ and 60$) \mathrm{cm}$ and three water heads $(3,4$, and $6 \mathrm{~m})$ with an operation time of 300 minutes. They showed that maximum soil moisture vertical expansion occurred at maximum pressure head of $6 \mathrm{~m}$ that was equal to double length of the pipe. Reference [9], conducted experiments with $40 \mathrm{~cm}$ pipes lengths made of clay soil, with hydraulic heads of $(25,50,100$ and $200 \mathrm{~cm}$ ), and with 5 days operation time on various soil textures. A simulation with HYDRUS 2D/3D has been worked in different water pressures. They showed that when increase the applied head of the system cause increasing the size of the wetting pattern, and the depth of installation has a large effect on the recommended horizontal spacing and the amount of evaporation loss. Reference [7], used -NPDI- Negative Pressure Difference Irrigation as a type of subsurface irrigation. Experimental work was done by using six porous pipes with different dimensions installed vertically, at a negative pressure of $-3 \mathrm{~cm}$, and for four hours as a supplied water. Experimental results showed that the wetting pattern of the soil is different for each kind of porous pipes, and the maximum expansion in a vertical and a radial direction vary with the change in length and diameter of the pipes.

The objectives of the present study were to predict soil water content distribution through sand and sandy loam soils, and to evaluate an empirical formulas for wetted width and depth as a function of operating time, pipe hydraulic conductivity, pipe length, applied head, and initial soil water content.

\section{Water Flow Equation}

The basic theory describe the flow of fluid in porous media was introduced in 1907 by Buckingham who identified that flow of water through unsaturated soils are extremely dependent upon water content. In 1931 Richard applied continuity equation to law of Buckingham which represent an extension to Darcy law. The Richards' equation for a two- dimensional isotropic medium is [1] and [2] :

$\frac{\partial \theta}{\partial t}=\frac{\partial}{\partial x}\left[K(h) \frac{\partial h}{\partial x}\right]+\frac{\partial}{\partial Z}\left[K(h) \frac{\partial h}{\partial Z}\right]+\frac{\partial K(h)}{\partial Z}$

where:

$\theta \quad=$ volumetric soil water content, $L^{3} / L^{3}$,

$t \quad=$ time, $T$, and

$K(h)=$ soil water conductivity which depend upon pressure head, $L / T$,

The solution to equation (1) requires initial and boundary conditions. The initial conditions are the dependent variables values which specify inside the domain of flow while the boundary conditions specified either the liquid flux along the boundary, the total potential across the boundary, or gathering of specified flux and head. Fig. (1) shows a typical section of the flow medium considered for present study that consists of two types of cells with various properties. The first type of cells are the pipe body $H G F E H$, while the second type are the cells that belong the soil outside the pipe body $A B C D E F G H A$.

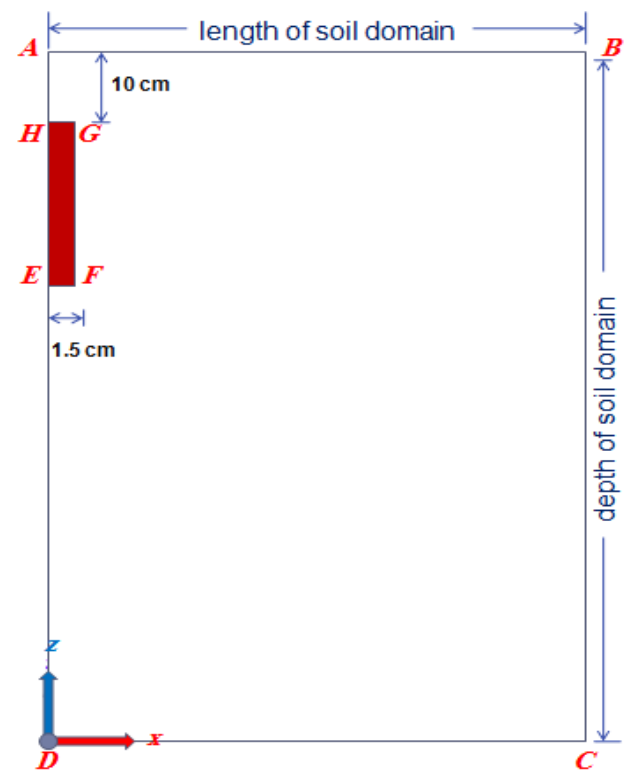

Fig. 1. A typical section of the flow medium considered for present study. 


\subsection{Assumptions}

The assumptions of this research are: the soil is homogeneous and isotropic, the initial water contents of soils are distributed in regular form through the soils, neglecting the soil surface evaporation during application of water, the wall of buried vertical ceramic pipe is saturated.

\subsection{Initial and Boundary Conditions}

The initial condition are given as:

$\theta(x, z, 0)=\theta_{i}$ on $A B C D E F G H A$

The boundary conditions are defined as:

$\left(\frac{\partial h}{\partial z}\right)=0$ no flux boundaries along $A B, H G$

$\left(\frac{\partial h}{\partial x}\right)=0$ no flux boundaries along $A H, E D, B C$

$h(x, z, t)=h_{p}$ variable heads at the pipe lines $G F$,

$F E$

$h(x, d, t)=0$ free drainage at bottom of the soil,

$C D$

where:

$d=$ depth of the lowest boundary at bottom of the soil. $(L)$

\section{Numerical Simulations}

Soil hydraulic properties were modeled by using the van Genuchten relationships [10]:

$$
\begin{aligned}
& \theta(h)=\left\{\begin{array}{c}
\theta_{r}+\frac{\theta_{s}-\theta_{r}}{\left(1+|\alpha h|^{n}\right)^{m}} h<0 \\
\theta_{s} \quad h \geq 0
\end{array}\right. \\
& K(h)=K s S_{e}^{l}\left[1-\left(1-S_{e}^{1 / m}\right)^{m}\right]^{2} \\
& S_{e}=\frac{\theta-\theta_{r}}{\theta_{s}-\theta_{r}} \\
& m=1-\frac{1}{n}
\end{aligned}
$$

where:

$\theta(h)$ water content as a function of pressure head, $L^{3} / L^{3}$,

$\theta_{r} \quad$ residual water content, $L^{3} / L^{3}$,

$\theta_{s} \quad$ saturated water content, $L^{3} / L^{3}$,

$\theta \quad$ volumetric soil water content, $L^{3} / L^{3}$,

$K(h)$ unsaturated hydraulic conductivity as a function of pressure head, $L / T$,

Ks saturated hydraulic conductivity of the soil, $L / T$,

$l$ pore conductivity parameter, dimensionless,

$n$ pore size distribution index, dimensionless,
$S_{e} \quad$ effective saturation, dimensionless, and

$\alpha \quad$ inverse of the air entry value, $L^{-1}$.

The van Genuchten model was fitted to the data and the model parameters used as inputs in HYDRUS/2D. These parameters are presented in Table (1).

Table 1,

Soil texture and related hydraulic properties.

\begin{tabular}{lllccc}
\hline $\begin{array}{l}\text { Soil } \\
\text { texture }\end{array}$ & $\begin{array}{c}\boldsymbol{K} \boldsymbol{s} \\
\boldsymbol{c m} / \boldsymbol{h} \boldsymbol{r}\end{array}$ & $\begin{array}{c}\boldsymbol{\theta}_{\boldsymbol{r}} \\
\boldsymbol{c m}^{3} / \mathbf{c m}^{\mathbf{3}}\end{array}$ & $\begin{array}{c}\boldsymbol{\theta}_{\boldsymbol{s}} \\
\boldsymbol{c m}^{3} / \boldsymbol{c m}^{3}\end{array}$ & $\begin{array}{c}\boldsymbol{\alpha} \\
\boldsymbol{c m}^{-\boldsymbol{1}}\end{array}$ & $\boldsymbol{n}$ \\
\hline $\begin{array}{l}\text { Sand } \\
\text { Sandy }\end{array}$ & 29.7 & 0.045 & 0.430 & 0.145 & 2.68 \\
loam & 4.42 & 0.065 & 0.410 & 0.075 & 1.89 \\
\hline
\end{tabular}

The wetting patterns from a buried vertical ceramic pipe were simulated by using two types of soils (sand, and sandy loam) through soil classification of United States Department of Agriculture, (USDA). The initial water contents of the soil enclose between residual and saturated water contents which differ in each soil as shown in Table (2).

Table 2,

Values of initial soil water content used for the simulations in USDA classification system.

\begin{tabular}{llllll}
\hline Soil texture & \multicolumn{5}{l}{$\begin{array}{l}\text { Initial volumetric soil water content, } \\
\boldsymbol{\theta}_{\boldsymbol{i}}, \mathbf{c m}^{\mathbf{3}} \mathbf{\mathbf { c m } ^ { 3 }}\end{array}$} \\
\hline Sand & 0.05 & 0.06 & 0.07 & 0.08 & 0.09 \\
Sandy loam & 0.07 & 0.085 & 0.1 & 0.115 & 0.13 \\
\hline
\end{tabular}

Heads that applied at the soil surface differ according to soil type which illustrated in Table (3).

Table 3,

Values of applied hydraulic heads at soil surface.

Soil texture Applied head, $\mathrm{h}, \mathrm{cm}$

\begin{tabular}{llllll}
\hline Sand & 50 & 75 & 100 & 125 & 150 \\
Sandy loam & 25 & 50 & 100 & 150 & 200 \\
\hline
\end{tabular}

In each head $10 \mathrm{~cm}$ was added as a buried depth of the ceramic pipe. The hydraulic conductivities of the buried vertical ceramic pipe varied in soils also according to soil type that shown in Table (4). 
Table 4,

Values of hydraulic conductivity of the buried ceramic pipe.

\begin{tabular}{llllll}
\hline $\begin{array}{l}\text { Soil } \\
\text { texture }\end{array}$ & \multicolumn{5}{l}{ Pipe hydraulic conductivity, $\boldsymbol{K}_{\boldsymbol{s}}, \boldsymbol{c m} / \boldsymbol{h r}$} \\
\hline $\begin{array}{l}\text { Sand } \\
\text { Sandy }\end{array}$ & 0.05 & 0.06 & 0.07 & 0.08 & 0.09 \\
loam & 0.05 & 0.1 & 0.2 & 0.25 & 0.3 \\
\hline
\end{tabular}

\section{Statistical Analysis}

Three statistical parameters, root mean square error (RMSE), mean absolute percentage error (MAPE), and coefficient of determination $\left(\mathrm{R}^{2}\right)$ were used to test the discrepancy between the results obtained from HYDRUS and the results obtained from the empirical formulas. These parameters are defined as [11].

\section{a- Root mean square error (RMSE)}

$\mathrm{RMSE}=\sqrt{\frac{\sum_{i=1}^{N}\left(M_{i}-S_{i}\right)^{2}}{N}}$

b- Mean absolute percentage error (MAPE)

MAPE $=\frac{1}{N} \sum \frac{\left(M_{i}-S_{i}\right)}{M_{i}} * 100$

\section{c- Coefficient of determination $\left(\mathbf{R}^{2}\right)$}

$\mathrm{R}^{2}=1-\frac{\sum_{i=1}^{N}\left(M_{i}-S_{i}\right)^{2}}{\sum_{i=1}^{N}\left(M_{i}-\bar{M}\right)^{2}}$

where:

$M_{i}=$ measured wetted dimensions obtained from HYDRUS/2D, $L$,

$S_{i}=$ calculated wetted dimensions by using the empirical formula, $L$,

$N=$ total number of data, and

$\bar{M}=$ mean values of measured wetted dimensions obtained from HYDRUS/2D, $L$.

\section{Results and Discussion \\ 5. 1. Wetting Patterns}

The software HYDRUS/2D used to predict the soil wetting patterns under several boundary conditions. The simulations of wetting patterns were carried out at the right side because of symmetry for the wetting patterns. The ceramic pipe located at $10 \mathrm{~cm}$ below the upper boundary on the left side of the rectangular domain, $1.5 \mathrm{~cm}$ wide, and with different pipes lengths $(10,20,30$, 40 , and $50 \mathrm{~cm}$ ). Fig. 2 shows simulations in sand and sandy loam soils with different domain, while the effects of applied head, pipe hydraulic conductivity, and pipe length respectively in sandy loam soil are shown in Fig.3 through Fig.5.

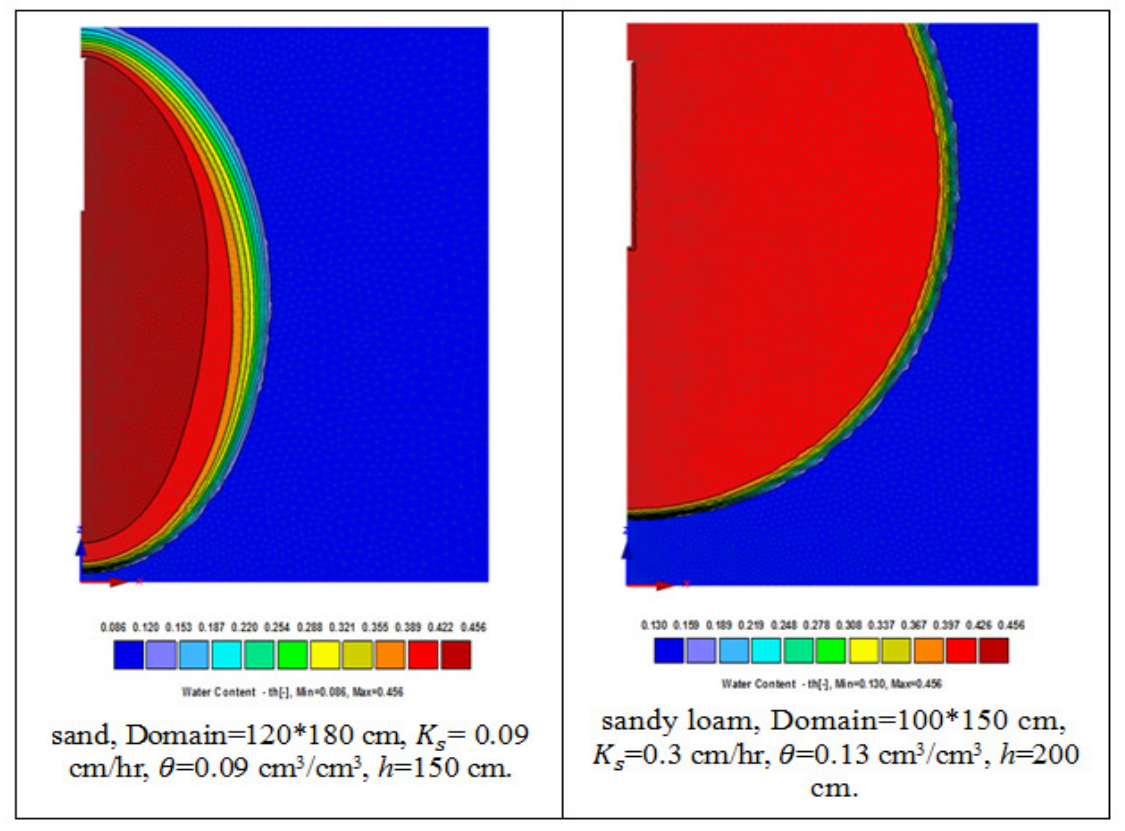

Fig. 2. Simulation of wetting patterns from a ceramic pipe in sand and sandy loam soils with pipe length of 50 $\mathrm{cm}$, and after $1.5 \mathrm{hr}$ operating times. 


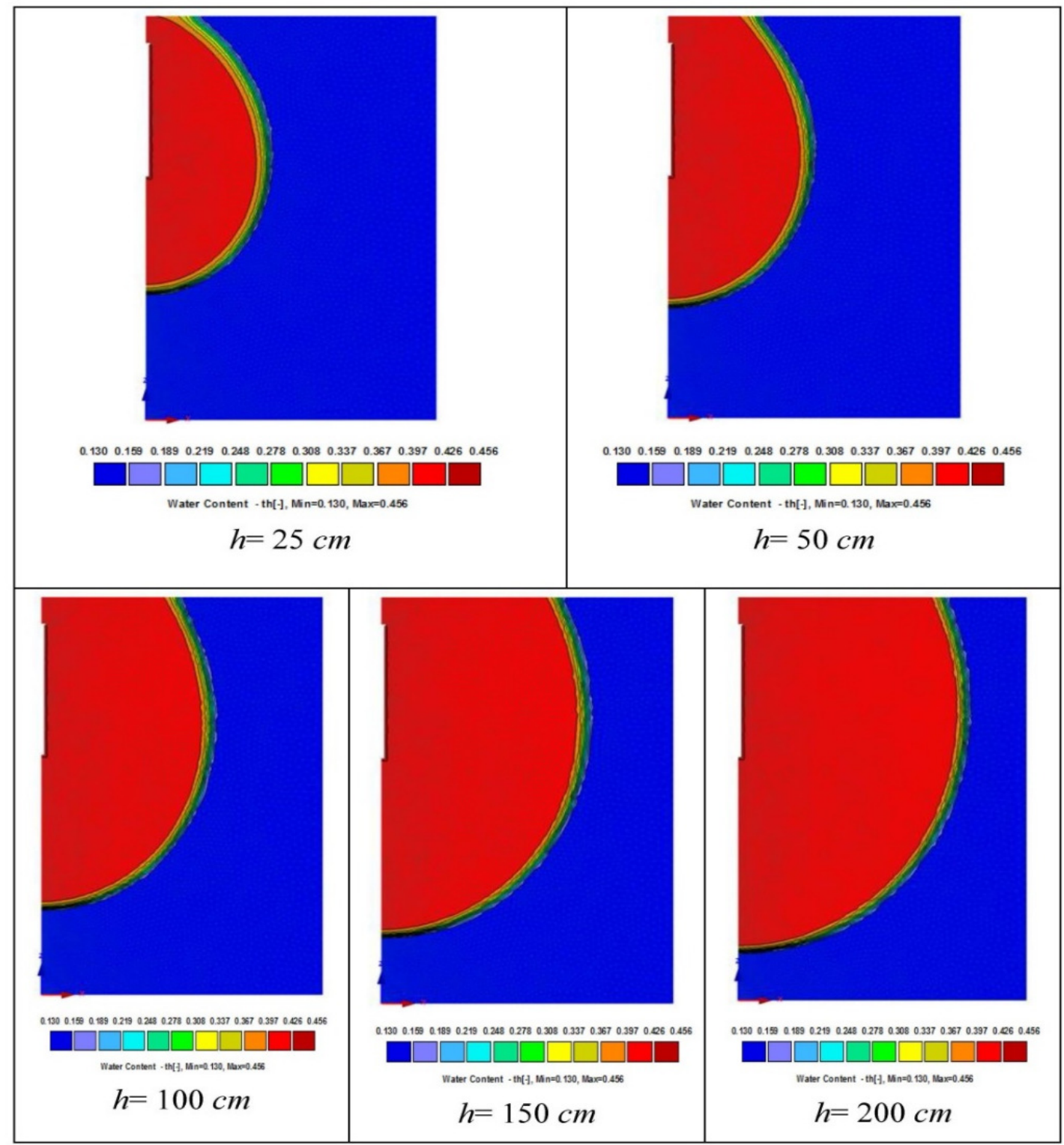

Fig. 3. Simulation of wetting patterns from a ceramic pipe in sandy loam soil with $1.0 \times 1.5 \mathrm{~m}$ domain, pipe length $=50 \mathrm{~cm}$, pipe hydraulic conductivity $=0.3 \mathrm{~cm} / \mathrm{hr}$, initial soil water content $=0.13 \mathrm{~cm}^{3} / \mathrm{cm}^{3}$, and with different applied heads after $1.5 \mathrm{hr}$. 


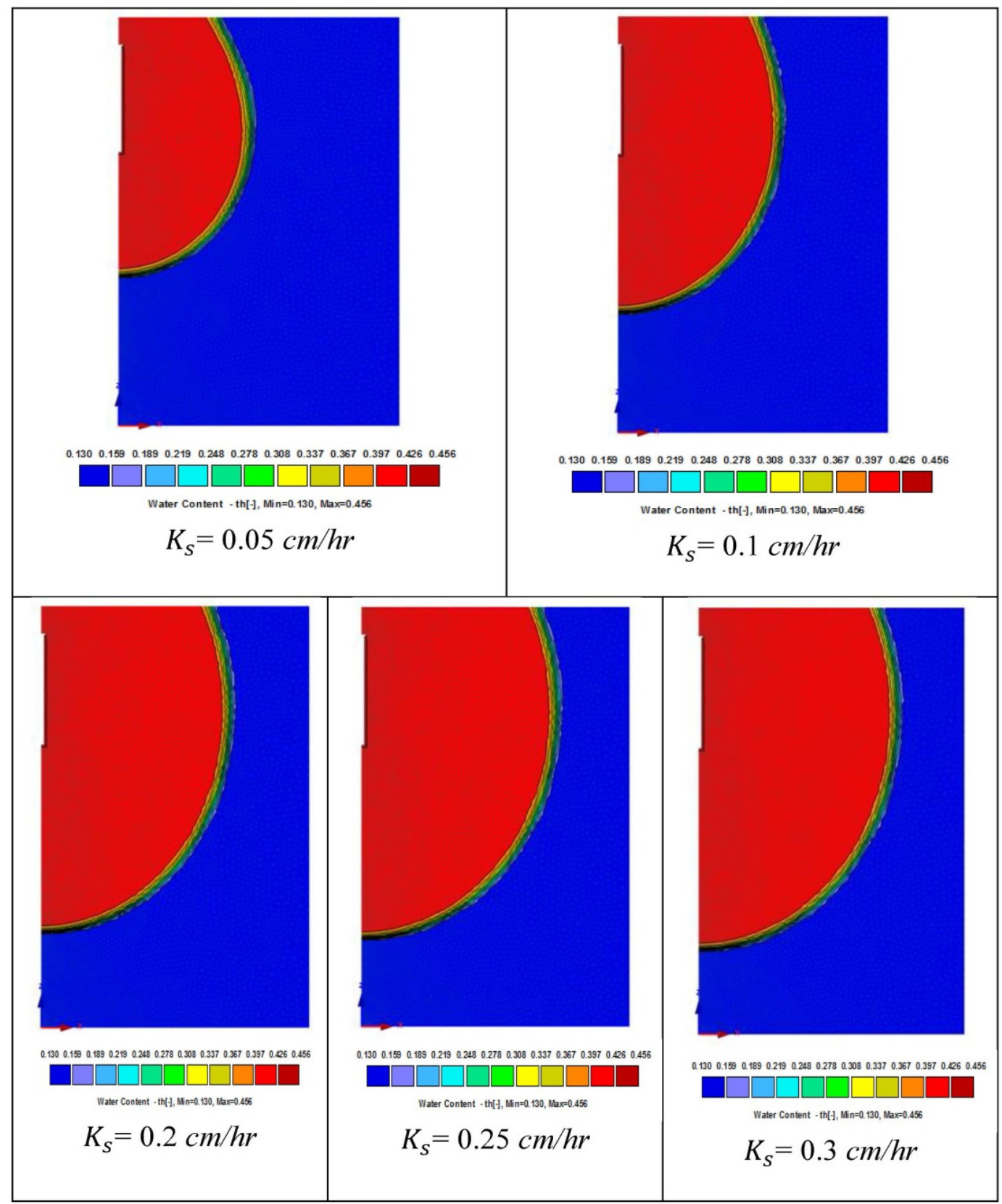

Fig. 4. Simulation of wetting patterns from a ceramic pipe in sandy loam soil with $1.0 \times 1.5 \mathrm{~m}$ domain, pipe length $=40 \mathrm{~cm}$, initial soil water content $=0.13 \mathrm{~cm}^{3} / \mathrm{cm}^{3}$, applied head $=200 \mathrm{~cm}$, and with different pipe hydraulic conductivities after $1.5 \mathrm{hr}$. 


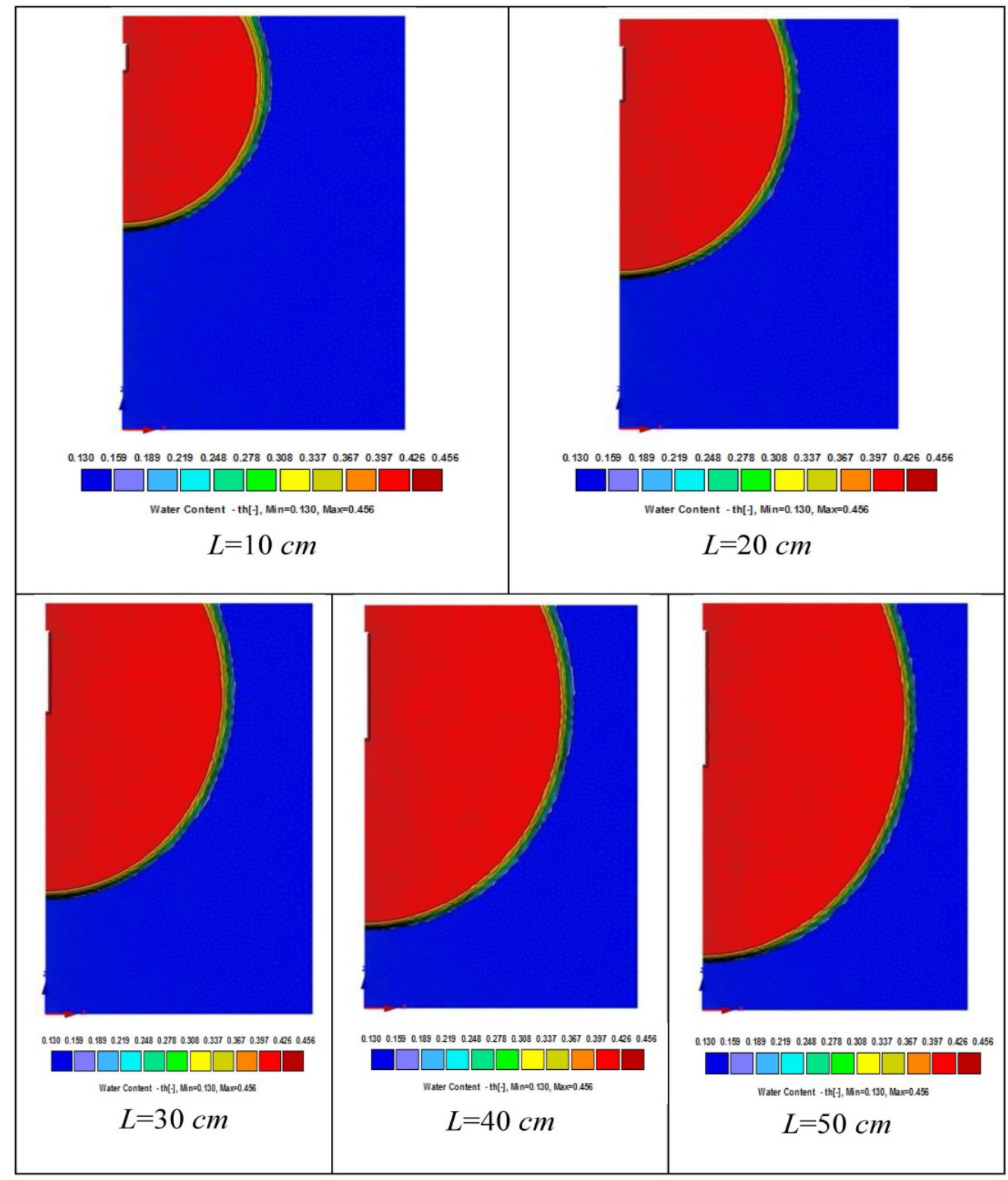

Fig. 5. Simulation of wetting patterns from a ceramic pipe in sandy loam soil with $1.0 \times 1.5 \mathrm{~m}$ domain, initial soil water content $=0.13 \mathrm{~cm}^{3} / \mathrm{cm}^{3}$, pipe hydraulic conductivity $=0.3 \mathrm{~cm} / \mathrm{hr}$, applied head $=200 \mathrm{~cm}$, and with different pipe lengths after $1.5 \mathrm{hr}$.

\subsection{The Empirical Formulas}

In this section STATISTICA software version 10 was used to develop formulas to predict wetted width and depth for each soil texture. This program work with a multiple regression analysis. In each type of soil numerous data were obtained from HYDRUS/2D, about 7500 value for maximum wetted width and 7500 value for maximum wetted depth. The obtained data were gathered in the STATISTICA software that were operating time, the maximum wetted width, the maximum wetted depth, pipe hydraulic conductivities, pipe lengths, applied heads, and initial soil water contents as an input data. Table (5) and Table (6) show the empirical formula of wetted width and depth, respectively.

Table 5,

Empirical formulas to predict the wetted width.

\begin{tabular}{ll}
\hline $\begin{array}{l}\text { Soil } \\
\text { texture }\end{array}$ & Wetted width, $\boldsymbol{X}, \boldsymbol{c m}$ \\
\hline Sand & $7.599 t^{0.471} K_{S}^{0.433} L^{0.354} h^{0.335} \theta^{0.099}$ \\
Sandy loam & $6.301 t^{0.481} K_{S}^{0.290} L^{0.314} h^{0.341} \theta^{0.137}$ \\
\hline
\end{tabular}


Table 6,

Empirical formulas to predict the wetted depth.

Soil

\begin{tabular}{ll} 
texture & Wetted depth, $\boldsymbol{Z}, \mathbf{c m}$ \\
\hline Sand & $16.891 t^{0.396} K_{S}^{0.275} L^{0.521} h^{0.208} \theta^{0.108}$
\end{tabular}

Sandy loam $13.493 t^{0.229} K_{s}^{0.126} L^{0.470} h^{0.123} \theta^{0.086}$

Verification of an empirical formulas was done by comparing the values of measured and calculated wetted dimensions. The relative error used to find the discrepancy between measured and calculated values of wetted dimensions. Table (7) shows the comparison for pipe length of $10 \mathrm{~cm}$ for sand soil.

Table 7,

Comparison of calculated wetted dimensions with measured for ceramic pipe length equals $10 \mathrm{~cm}$ for sand soil.

\begin{tabular}{|c|c|c|c|}
\hline \multicolumn{4}{|c|}{ Wetted width", $\mathrm{cm}$} \\
\hline $\begin{array}{l}\text { Time, } \\
h r\end{array}$ & Calculated & Measured $^{* *}$ & $\begin{array}{l}\text { Relative } \\
\text { Error, \% }\end{array}$ \\
\hline 0.25 & 6.63 & 7 & 5.3 \\
\hline 0.5 & 9.19 & 10 & 8.1 \\
\hline 1 & 12.73 & 11.5 & 10.7 \\
\hline \multicolumn{4}{|c|}{ Wetted depth ${ }^{*}, \mathrm{~cm}$} \\
\hline $\begin{array}{l}\text { Time, } \\
h r\end{array}$ & Calculated & Measured $^{* *}$ & $\begin{array}{l}\text { Relative } \\
\text { Error, \% }\end{array}$ \\
\hline 0.25 & 22.29 & 27 & 17.4 \\
\hline 0.5 & 29.34 & 32 & 8.3 \\
\hline 1 & 38.6 & 39 & 1 \\
\hline
\end{tabular}

*saturated hydraulic conductivity of ceramic pipe $=0.056 \mathrm{~cm} / \mathrm{hr}$, initial soil water content $=0.026$, and applied head $=50 \mathrm{~cm}$.

** according to (Al-Merib, 2014).

The statistical comparison between wetting pattern sizes (width and depth) obtained by using HYDRUS/2D and those predicted by the empirical formulas is shown in Table (8) and Table (9).

Table 8,

Statistical analysis of the comparison between wetting patterns width obtained by using HYDRUS/2D and those predicted by the empirical formulas.

\begin{tabular}{llll}
\hline Soil texture & RMSE, $c m$ & $\mathbf{R}^{\mathbf{2}}$ & $\begin{array}{l}\text { Average } \\
\text { RE \% }\end{array}$ \\
\hline Sand & 0.87 & 0.991 & 3.72 \\
Sandy loam & 1.37 & 0.991 & 4.33 \\
\hline
\end{tabular}

Table 9,

Statistical analysis of the comparison between wetting patterns depth obtained by using HYDRUS/2D and those predicted by the empirical formulas.

\begin{tabular}{llll}
\hline Soil texture & RMSE, $c m$ & $\mathbf{R}^{2}$ & $\begin{array}{l}\text { Average } \\
\text { RE \% }\end{array}$ \\
\hline Sand & 4.1 & 0.981 & 4.48 \\
Sandy loam & 3.59 & 0.972 & 4.51 \\
\hline
\end{tabular}

\section{Conclusions}

The method of subsurface irrigation is becoming increasingly popular especially in developed nations. The main aims of this research are to predict soil water content distribution through two types of soils (sand and sandy loam), and to evaluate an empirical formulas for wetted width and depth as a function of operating time, pipe hydraulic conductivity, pipe length, applied head, and initial soil water content. The results showed that the wetting patterns extend vertically much more than horizontal direction especially in sand soil, the wetting patterns increase as the length of ceramic pipes increase, but few increase in horizontal direction when compare with vertical direction. The wetting patterns increase in both directions as the applied heads increase. The wetting patterns increase as the hydraulic conductivities of the pipe increase. The initial soil water contents have few effect on the wetting patterns, finally the empirical formulas for wetted width and depth are good and can be used as designed equations.

\section{Notation}

$h$ pressure head, $L$

Ks saturated hydraulic conductivity of the soil, $L / T$

$K_{S} \quad$ saturated hydraulic conductivity of the ceramic pipe, $L / T$

$K(h)$ unsaturated hydraulic conductivity as a function of pressure head, $L / T$

$L \quad$ length of ceramic pipe, $L$

$l \quad$ pore conductivity parameter, dimensionless

$n \quad$ pore size distribution index, dimensionless

$S_{e} \quad$ effective saturation, dimensionless

$t \quad$ time, $T$

$X \quad$ wetted width, $L$

$Z \quad$ wetted depth, $L$ 


\section{Greek letters}

$\alpha \quad$ inverse of the air entry value, $L^{-1}$

$\theta \quad$ volumetric soil water content, $L^{3} / L^{3}$

$\theta_{i} \quad$ initial soil water content, $L^{3} / L^{3}$

$\theta_{r} \quad$ residual water content, $L^{3} / L^{3}$

$\theta_{s} \quad$ saturated water content, $L^{3} / L^{3}$

$\theta(h)$ water content as a function of pressure head, $L^{3} / L^{3}$

\section{References}

[1] Abid, M. B., 2006, Analytical Solution of Unsaturated Soil Water Flow from a Point Source, Ph.D. thesis, Department of Water Resources Engineering, College of Engineering, University of Baghdad, Baghdad, Iraq.

[2] Abid, M. B., Hamad, S. N., and Hussain, S. M., 2012, Analytical Solution of Unsaturated Soil Water Flow from a Point Source, Journal of Engineering, vol.18, No.1, PP.95-106.

[3] Akhoond-Ali, A. M., and Golabi, M., 2008, Subsurface Porous Pipe Irrigation with Vertical Option as a Suitable Irrigation Method for Light Soil, Asain J. of Scientific Research, vol.1, no.3, pp.180-192.

[4] Al-Merib, F. H., 2014, Flow from Buried Vertical Ceramic Pipes through Soils, Ph.D. thesis, Department of Water Resources Engineering, College of Engineering, University of Baghdad, Baghdad, Iraq.

[5] Ashrafi, S., Gupta, A. D., Babel, M. S., Izumi, N. and Loof, R., 2002, Simulation of
Infiltration from Porous Clay Pipe in Subsurface Irrigation, Hydrological Sciences Journal, vol.47, no.2, pp.253-268.

[6] Bainbridge, D. A., 2001, Buried Clay Pot Irrigation: a Little Known but Very Efficient Traditional Method of Irrigation, Agric. Water Manage, vol.48, no.2, pp.79-88.

[7] Khan, N. N., Islam, M. M., Islam , S., and Moniruzzaman, S. M., 2015, Effect of Porous Pipe Characteristics of Soil Wetting Pattern in a Negative Pressure Difference Irrigation System, American Journal of Engineering Research (AJER), vol.4, no.2, pp.01-12.

[8] Qiaosheng, S., Zuoxin, L., Zhenying, W., and Haijun, L., 2007, Simulation of the Soil Wetting Shape under Porous Pipe SubIrrigation Using Dimensional Analysis, Irrig. Drain. vol.56, pp.389-398.

[9] Siyal, A. A., and Skaggs, T. H., 2009, Measured and Simulated Soil Wetting Patterns under Porous Clay Pipe Sub-Surface Irrigation, Agricultural Water Management, vol.96, pp.893-904.

[10] Van Genuchten, M. Th., (1980), "A closedform equation for predicting the hydraulic conductivity of unsaturated soils". Soil Sci. Soc. Amer. J., vol. 44, pp. 892-898.

[11] Willmott, C. J., (1982), "Some comments on the evaluation of model performance". Bulletin of the American Meteorological Society, vol. 63, no. 11, pp. 1309-1313. 


\title{
نموذج عددي لحركة الماء من أنابيب سيراميك مدفونة بشكل عمودي من خلال الترب الخشنة
}

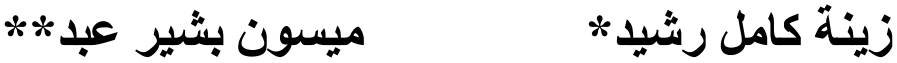

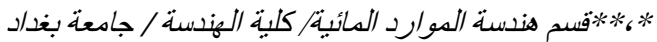 \\ email:dr.maysoonbasheer @gmail.com البريد الالكتروني \\ email:kamel_zena @yahoo.com البريد الالكتروني: ***
}

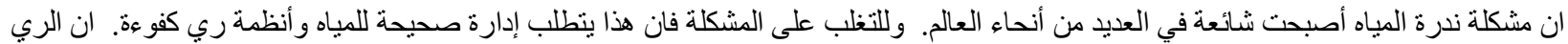

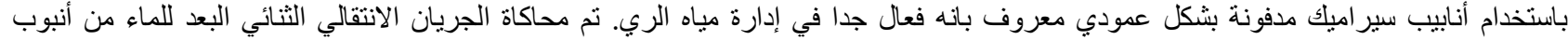

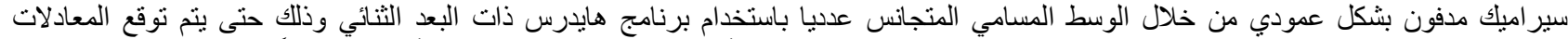

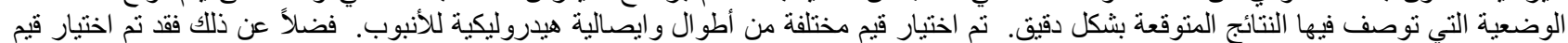

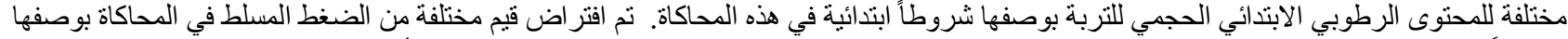

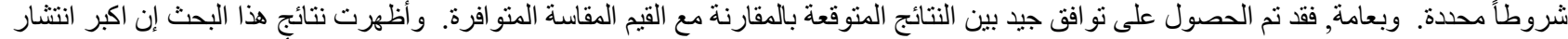

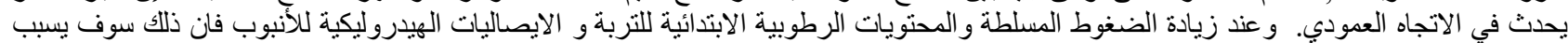

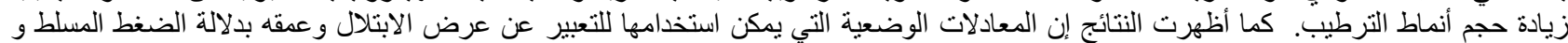

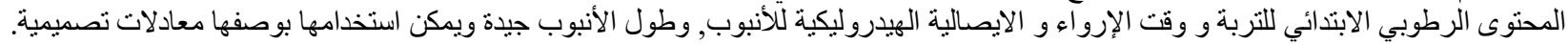

